\title{
MEMORIAL ESCOLAR: UMA PRODUÇÃO SIGNIFICATIVA
}

- LUANNA PRISCILA DA SILVA GOMES

https://orcid.org/0000-0002-7157-6870

Universidade Federal do Rio Grande do Norte

PATRÍCIA LÚCIA GALVÃO DA COSTA

https://orcid.org/0000-0002-2481-9411

Universidade Federal do Rio Grande do Norte

- CLÁUDIA ROBERTO SOARES DE MACÊDO NAZÁRIO

https://orcid.org/0000-0002-2792-3812

Universidade Federal do Rio Grande do Norte

RESUMO A escrita de um memorial escolar constitui-se como prática pedagógica realizada com alunos do 5o ano do Núcleo de Educação da Infância (NEI) - Colégio de Aplicação (CAp) da Universidade Federal do Rio Grande do Norte (UFRN). A partir dessa produção, nos questionamos sobre o que as crianças pensam acerca da escola e de suas práticas. Assim, o presente artigo se configura como uma pesquisa qualitativa na vertente (auto)biográfica e objetiva, de modo geral, analisar a prática do memorial escolar como uma possibilidade de escrita em uma perspectiva reflexiva e, especificamente, investigar reflexões e concepções das crianças sobre a escola e algumas práticas escolares. A investigação foi realizada a partir da leitura de dois livros de memórias escolares escritos por crianças do 5o ano matutino, nos anos de 2018 e de 2019 do NEI-CAp/UFRN. A análise apontou a prática do memorial escolar como uma possibilidade de escrita reflexiva, significativa para crianças e professores. Possibilita ao professor pesquisar sobre sua prática e às crianças, uma formação consciente das experiências vividas. Enquanto protagonistas de sua vida escolar, por meio da escrita do memorial, as crianças definiram, de um modo simples e peculiar, a escola e suas práticas como lugar positivo, de exercício de direitos.

Palavras-chave: Memorial escolar. Narrativas. Crianças. Anos iniciais do ensino fundamental. Pesquisa (auto)biográfica. 


\section{SCHOOL MEMORIAL: A SIGNIFICANT PRODUCTION}

The writing of a school memorial is a pedagogical practice carried out with students of the 5th grade of the Center for Childhood Education - College of Application of the Federal University of Rio Grande do Norte (NEI-CAp / UFRN). From this production, we ask ourselves what the children think about the school and its practices. Thus, this article is configured as a qualitative research in the (auto) biographical aspect and aims, in general, to analyze the school memorial practice as a possibility of writing in a reflective perspective, and, specifically, to investigate the children's reflections and conceptions. about the school and some school practices. The investigation was carried out by reading two school memo books written by children of the 5th grade (morning), in the years 2018 and 2019 of the NEI-CAp I UFRN. The analysis pointed to the school memorial practice as a possibility of reflective writing, significant for children and teachers. It allows the teacher to research about his practice and to the children, a conscious formation of the lived experiences. As protagonists of their school life, through the writing of the memorial, the children defined, in a simple and peculiar way, the school and its practices as a positive place for exercising rights.

Keywords: Memorial Escolar. Narratives. Children. Early Years of Elementary School. (Auto) biographical research.

\section{MEMORIAL ESCOLAR: UNA PRODUCCIÓN}

\section{SIGNIFICATIVA}

La escritura de un memorial escolar es una práctica pedagógica que se lleva a cabo con estudiantes del 5o año del Centro de Educación Infantil - Escuela de Aplicación de la Universidad Federal de Rio Grande do Norte (NEI-CAp/UFRN). Sobre la base de esta producción, nos preguntamos sobre qué piensan los niños acerca de la escuela y sus prácticas. Así, este artículo está configurado como una investigación cualitativa en el aspecto (auto) biográfico y tiene como objetivo, en términos generales, analizar la práctica del memorial escolar como una posibilidad de escribir en una perspectiva reflexiva y, específicamente, investigar las reflexiones y concepciones de los niños sobre la escuela y algunas prácticas escolares. La investigación se desarrolló a partir de la lectura de dos libros de recuerdos escolares escritos por niños del 5o año del turno de mañana, en los años 2018 y 2019 del NEI-CAp/UFRN. El análisis subrayó la práctica del memorial escolar como una posibilidad de escritura reflexiva, significativa para niños y maestros. Permite al maestro investigar sobre su práctica; 
y a los niños una formación consciente de las experiencias vividas. Como protagonistas de su vida escolar, a través de la escritura del memorial, los niños definieron, de una manera simple y peculiar, la escuela y sus prácticas como un lugar positivo para el ejercicio de los derechos.

Palabras clave: Memorial Escolar. Narrativas. Niños. Años Iniciales de la Escuela Primaria. Investigación (auto) biográfica.

\section{Introdução}

Docentes do Núcleo de Educação de Infância (NEI) - Colégio de Aplicação (CAp) da Universidade Federal do Rio Grande do Norte (UFRN) propõem, desde 2017, a escrita de um memorial escolar em turmas do 5o ano do ensino fundamental. Essa prática foi motivada pelos professores com o fim de resgatar o percurso vivido pelas crianças desde o momento de entrada na instituição até o 5 o ano, que se constitui como o último ano delas na escola (FERNANDES; SOUZA; FREITAS, 2017).

Assim, enquanto docentes do 5o ano de 2018 e 2019 no turno matutino, participamos ativamente de mediações que levaram à produção de memoriais escolares com essas turmas, nos respectivos anos. Então, a partir de nossas vivências, das contribuições acadêmicas sobre a relevância da pesquisa (auto)biográfica na pesquisa escolar (PASSEGGI, 2001), nos questionamos sobre o que as crianças pensam acerca da escola e de suas práticas, e partimos para a leitura dos seus textos memorialísticos (NAZÁRIO; COSTA, 2018; GOMES; COSTA, 2019).

Consideramos o pressuposto de que as crianças são sujeitos de direitos (PASSEGGI et al., 2014) e, por assim serem, merecem ser consideradas em sua completude, sendo respeitados o seu pensamento; movimento; ação; emoção; seus modos de observar e de representar o mundo; de ser e de viver em sociedade.

Um modo de garantirmos esses direitos se dá pela via da oportunização de espaços em que elas possam ser ouvidas e entendidas em suas singularidades e por diversos modos de expressão. Dessa forma, diante de tantas possibilidades, optamos por ouvi-las, por meio da discussão, da escrita, ilustração e produção de um memorial escolar, no formato de um livro digital.

Passeggi, Nascimento e Oliveira (2016) abordam a narrativa (auto)biográfica como uma forma de narração que possibilita a (re) significação de experiências de vida. Em nosso caso, a escrita de histórias da vida escolar com crianças do 5o ano do ensino fundamental se configura para nós, professoras-pesquisadoras, que refletimos constantemente sobre nossas práticas, como uma forma de melhor compreender como essas crianças ativamente vivem e sentem a escola e as diversas práticas do cotidiano escolar a elas oportunizadas. Passeggi e Souza (2017, p. 8, grifo do autor) afirmam que:

[...] o sujeito em todas as fases da vida, apropria-se de instrumentos semióticos (a linguagem, o grafismo, o desenho, os gestos, as imagens, etc.) para contar suas experiências sob a forma de uma narrativa autobiográfica que até então não existia. E nesse processo de biografização, a pessoa que narra, embora não possa mudar os acontecimentos, pode reinterpretá -los dentro de um novo enredo, reinventandose com ele.

Portanto, ao escreverem suas memórias, as crianças ressignificam suas vivências escolares, tornando essa ação de escrita da narrativa, 
um "processo permanente de aprendizagem e de constituição sócio histórica da pessoa que narra" (PASSEGGI; SOUZA, 2017, p. 9).

0 memorial escolar, como gênero escolhido para as crianças escreverem sobre sua trajetória na escola, foi uma forma adaptada do memorial acadêmico, esse, narra experiências acadêmicas, na qual na qual a pessoa que narra "interpreta a trajetória de formação e atuação profissional" (BARBOSA, 2011, p. 204).

0 memorial escolar visa retomar, de forma reflexiva, momentos vividos na escola, instantes que proporcionam a constituição da identidade pessoal e estudantil da criança como aluno(a). Enquanto gênero textual é uma escrita institucional de si porque ele é elaborado como parte das atividades escolares que o autor produz com o objetivo de contar aspectos da sua vida escolar, sejam eles: aprendizagens, aspectos positivos e negativos, avanços, erros, sentimentos, dentre outros. A palavra "memorial" tem sua origem no latim e, segundo Silva (2014), deriva de "memória". o memorial se caracteriza como um texto narrativo, que os alunos descrevem passagens importantes de suas vidas, no caso analisado, aquelas da vida escolar.

Nesse processo, como professoras do 5으 ano em 2018 e 2019, nos questionamos, conforme elucidado anteriormente, acerca da compreensão da escola pelas crianças, do que sentem, das dificuldades, preferências e do que pensam sobre práticas pessoais e coletivas vivenciadas no ambiente escolar. Para responder aos nossos questionamentos, recorremos ao que foi registrado pelas crianças, ou seja, nossas análises incidem no que as crianças dizem acerca da escola e de suas práticas - aulas de matemática, momentos de leitura e brincadeiras -, tomando por base a potencialidade da escrita do memorial feito por elas.

A escrita de si, de acordo com Passeggi e Rocha (2012), viabiliza justamente a reflexão e atribuição de sentido. Assim, nessa perspectiva reflexiva, é possivel compreender por meio do registro escrito, o que as crianças dizem sobre a escola. Para nós professoras, conhecer as concepções das crianças se configura como um rico instrumento de formação profissional. Além disso, essa escrita também fomenta nas crianças um processo de reflexão e um possivel reconhecimento de aspectos positivos e negativos de sua trajetória no NEI.

Sendo assim, o presente artigo apresenta resultados de uma pesquisa qualitativa que se configura na vertente (auto)biográfica (PASSEGGI; NASCIMENTO; RODRIGUES, 2018) e tem como objetivo geral analisar a prática do memorial escolar como uma possibilidade de escrita em uma perspectiva reflexiva. Como objetivo específico, pretendemos apresentar reflexões e discutir as percepções das crianças sobre a escola e as seguintes práticas escolares: aulas de matemática, momentos de leitura, brincadeiras, que emergiram da leitura do corpus que está constituído por dois livros digitais organizados por Nazário; Costa (2018) e Gomes; Costa (2019) com a escrita das crianças do 5 o ano do turno matutino, nos anos letivos de 2018 e de 2019, no NEI - CAp da UFRN.

Por valorizarmos a escrita das crianças e os seus significados, é que privilegiamos a pesquisa qualitativa nos termos apresentados por Bogdan e Biklen (1994). Na pesquisa qualitativa, tentamos capturar a perspectiva dos sujeitos e a maneira como eles se referem às questões que estão sendo exploradas. Por isso, o procedimento metodológico para a análise das fontes se realizou da seguinte maneira: inicialmente, lemos os textos escritos pelas crianças; em seguida, realizamos uma segunda leitura e buscamos trechos que expressassem sentimentos acerca da escola e de práticas, o que nos permitiu identificar como recorrente a leitura, as aulas de matemática e as brincadeiras. Baseadas em 
Passeggi, Nascimento e Rodrigues (2018), organizamos essas informações em um quadro e analisamos os textos memorialísticos das crianças do 5o ano do NEl.

O NEl é um Colégio de Aplicação, criado em 1979, com o objetivo inicial de atuar como creche para atender ao público universitário feminino (filhos a partir dos três meses de alunas, professoras e servidoras da UFRN). Com o passar dos anos, houve ampliação do ingresso das crianças para a comunidade em geral, de modo que a entrada de crianças na instituição passou a ser e acontece até hoje, por meio de um sorteio público, no qual qualquer cidadão, independente de possuir ligação com a universidade ou não, pode inscrever seu filho(a), a partir de edital publicado pela UFRN, como forma de acesso à escola. Hoje, a instituição tem um total de 409 alunos, e recebe crianças desde um ano de idade na educação infantil, que em geral permanecem até o 5o ano do ensino fundamental, último ano escolar ofertado pelo NEI.

As crianças que realizaram a produção dos memoriais ingressaram, portanto, na instituição via sorteio. As de 2018 , entraram no 1o ano do ensino fundamental e, as de 2019 , entraram na educação infantil. Nesse percurso, colecionaram diversas memórias desde os primeiros anos na escola, as quais foram resgatadas na finalização da etapa dos anos iniciais do ensino fundamental. Tal resgate, culminou na construção dos textos memorialísticos aqui analisados, cujo intuito ao final do ano, era a produção de um livro digital de memórias que narrasse suas trajetórias na instituição.

A turma do 5o ano 2018, constituída por 21 alunos, sendo 8 meninos e 13 meninas. A turma de 2019, por 15 alunos, sendo 10 meninos e 5 meninas. Em ambas as turmas a faixa-etária variava entre 10 e 11 anos de idade. Em cada turma, as aulas são ministradas por dois professores. Em 2018, a segunda e terceira auto- ra deste artigo eram professoras da turma do 5o ano. Em 2019, a primeira e segunda autoras atuaram como docentes do 5o ano. Optamos por discutir aqui o processo de produção do memorial em dois anos consecutivos, uma vez que a segunda autora participou em 2018 e 2019 no turno matutino, o que possibilitou um olhar mais aguçado acerca do processo de implementação e da escrita do memorial escolar no NEI.

Para a apresentação do processo de escrita de memórias escolares, organizamos este texto em duas partes. Na primeira parte - Procedimentos de elaboração do memorial escolar - após expor de modo sintético nossas motivações para a elaboração de um livro de memórias escolares com crianças, focalizamos a organização do corpus, a contextualização do lócus da pesquisa e das crianças participantes, nosso procedimento de pesquisa e análise; em seguida, apresentamos algumas etapas vivenciadas na produção do memorial escolar, na sequência, analisamos reflexões e concepções acerca do âmbito escolar apresentadas nos textos das crianças e, por último, registramos nossas considerações finais.

\section{Procedimentos de elaboração do memorial escolar}

Considerando os aspectos anteriormente mencionados, como professoras das turmas do 5 o ano em 2018 e 2019, demos continuidade ao trabalho iniciado em 2017 no NEI. Para mostrar os principais momentos da experiência vivida nesses dois últimos anos, explicitamos a seguir algumas atividades realizadas no processo de produção do livro de memórias escolares.

Nossa prática pedagógica em sala de aula com a produção do memorial escolar foi embasada, inicialmente, nos apontamentos de Fernandes, Souza e Freitas (2017). Destacamos algumas motivações que levaram à escrita 
desse artigo': a segunda autora desse artigo (COSTA) tem uma trajetória de pesquisa sobre memoriais, tem Mestrado em Educação sobre esse assunto e participou dos dois anos do estudo (2018 e 2019); além disso, existem projetos de pesquisa com narrativas de crianças a partir do memorial escolar sendo realizados na UFRN, e esse artigo colabora com um desses projetos. Para fins de organização e exposição das mediações, neste artigo, separamos as atividades do processo de produção do livro de memórias escolares em etapas, que foram adaptadas dos estudos de Antunes (2003), a saber: para Antunes (2003), o processo de produção textual é constituído por três principais momentos: o de planejamento, o da escrita e o da reescrita. Em nosso caso, o processo não se esgotava na produção de texto, já que o processo de escrita culminava com a edição e publicação do livro. Portanto, as produções das crianças publicadas, além de cumprirem uma funcionalidade social, permite a visibilidade de suas narrativas escolares, e sua construção se constitui como importante processo de autorreflexão e autoria para as crianças.

Organizamos a produção do livro em etapas com o fim de valorizar as vivências das crianças e os seus escritos, de tal modo que servissem, por um lado, para elas, pelo processo de um olhar sobre si, sobre suas trajetórias, atribuir-lhes um significado e, por outro, para nós, professoras, enquanto possibilidade de refletirmos com as crianças sobre nossa própria prática de sala de aula.

Ressaltamos que nossa intenção neste subitem é descrever e analisar os procedimentos utilizados no processo de escrita, reescrita e publicação dos memoriais escolares.

0 momento inicial do processo de produção textual é definido por Antunes (2003)

10 artigo está vinculado ao projeto de pesquisa: PASSEGGI, M.C. "Narrativas infantis: o que contam as crianças sobre as escolas da infância" (MCTI-CNPq/ MEC-CAPES. Processo no 401519/2011-2. como o de planejamento. Essa é a etapa para se pensar e decidir acerca do que vai ser escrito. Esta fase é dedicada às leituras para a ampliação do repertório, reflexão sobre os objetivos da escrita e, no caso do memorial escolar, tentativas de buscar nas lembranças, fatos vivenciados na escola, desde a entrada na instituição.

Passeggi (2016) explica que para a escrita de si, o sujeito vivencia três momentos que ela denomina de iniciático (evocação), maiêutico (reflexão) e hermenêutico (interpretação). o contexto abordado pela autora refere-se à produção de memoriais de formação, elaborado por professores em formação inicial ou continuada. Mas, é possivel fazer um paralelo com a escrita do memorial escolar. No primeiro momento, a etapa iniciática, a criança se questiona sobre o memorial: como irá escrever sobre si? o que escrever? e de que modo irá lembrar dos acontecimentos com o fim de produzir essas memórias? O segundo momento, o maiêutico, acontece quando a criança já se sente mais confiante e consegue buscar nas suas memórias, as lembranças que viveram em anos anteriores e refletem sobre sua escrita, a partir das leituras, vivências, discussões e produções dos seus textos. No terceiro momento, o hermenêutico, a criança, depois das reescritas, também reinterpreta os acontecimentos narrados e, ao aguçar o seu olhar, dá novos sentidos às experiências vividas na escola e tira lições para a vida ao concluir a escrita do texto.

Para a etapa inicial, as turmas do 5o ano do NEI realizaram diversas atividades motivacionais, sempre considerando que a escrita do memorial escolar é colaborativa, uma vez que alunos, colegas, professores, pais e responsáveis também participam da produção. Assim, a etapa de planejamento é vivenciada também pelos familiares das crianças, conforme sintetizado no Quadro 1. 
Quadro 1 - Planejamento da escrita das memórias escolares

\begin{tabular}{|c|l|}
\hline \multirow{2}{*}{$\begin{array}{c}\text { Objetivos do planejamento da produção dos } \\
\text { textos que compóem o livro de memórias escolares }\end{array}$} & $\begin{array}{l}\text { Apreciar objetos com significados } \\
\text { memorialísticos }\end{array}$ \\
\cline { 2 - 3 } & $\begin{array}{l}\text { Conhecer o gênero textual memorial escolar } \\
\text { Entrevistar familiares acerca de suas memórias } \\
\text { escolares }\end{array}$ \\
\hline
\end{tabular}

Fonte: elaborado pelas autoras.

Nessa primeira etapa, realizamos uma série de atividades de preparação para a escrita propriamente dita. Para o objetivo "conhecer o gênero textual memorial escolar", fizemos um levantamento do que as crianças já sabiam sobre o memorial, em seguida, planejamos ações a partir do que elas tinham consolidado sobre o gênero em anos anteriores, as dúvidas que apresentavam, as lacunas, os interesses e, diante disso, propusemos exposições dialogadas sobre o gênero, mediada pelo uso de slides (produzidos no programa Power point), e por alguns exemplos de memoriais construídos na nossa sociedade, para que tivessem um contato inicial com a estrutura desse gênero.

Ainda com o mesmo objetivo de nos aprofundarmos nas características do gênero, promovemos uma discussão para diferenciar biografia, autobiografia, memorial e diário. Assim como realizamos leitura de textos literários que abordassem a memória e seu significado, constituindo-se como uma leitura espontânea da narrativa em diferentes momentos da rotina escolar, conforme orientado por Fernandes, Souza e Freitas (2017).

Para o segundo objetivo exposto no Quadro 1, propusemos que as crianças trouxessem de casa objetos que guardaram ao longo dos anos escolares no NEI-CAp/UFRN, para ilustrarem suas memórias escolares, de modo que pudessem recorrer a esses objetos para contarem suas histórias.

Nessa atividade, denominada por Fernandes, Souza e Freitas (2017) de "baú de memórias da turma", as crianças rememoraram por meio de objetos, fatos vividos na escola anos atrás. Objetos como fotografias, arquivos em vídeos, cadernos, livros, anotações, brinquedos, fardas, dentre outros, ajudaram as crianças a recordarem momentos especiais vivenciados na escola. Essa atividade se configurou como motivacional e despertou os sujeitos para acontecimentos e detalhes até então não recordados com tanta facilidade.

Outra atividade de planejamento para a etapa da escrita foi a realização de entrevistas com familiares dos estudantes; sempre que precisavam, as crianças podiam recorrer aos seus familiares para rememorarem o vivido. Essa experiência também fomentou a reflexão comparativa acerca de práticas antigas e atuais do cotidiano escolar, bem como o papel de ações como a leitura, a brincadeira, a escrita no contexto escolar e a valorização das memórias e práticas vivenciadas no âmbito escolar.

Após a realização de atividades com esse perfil, partimos para uma segunda etapa, que se caracteriza, segundo Antunes (2003), como a fase do sujeito registrar no papel o que foi planejado. É a etapa da escrita propriamente dita. Que apresenta os seguintes procedimentos: 
Quadro 2 - Alguns procedimentos da elaboração do memorial

1. Escrita espontânea das memórias escolares desde o ingresso no NEI

2. Leitura espontânea da narrativa, seja na roda inicial, seja na hora de história

3. Leitura crítica, pelos autores, da primeira versão do seu memorial escolar

4. Reescritas e reestruturação do texto de acordo com as discussões com as professoras e/ou colegas

5. Digitação do texto para produzir a versão final do memorial

6. Ilustração do memorial

7. Lançamento dos memoriais escolares

Fonte: elaborado pelas autoras.

Esses procedimentos serviram de guia para orientar o caminho percorrido pelos alunos desde os primeiros rascunhos até o lançamento. A cada 15 dias, dependendo do trabalho com a turma, sugeríamos um tema e as crianças escreviam em seu caderno sobre os temas propostos, como brincadeiras, festa junina, professores, tema livre, memórias literárias e matemáticas, viagens de estudo, amigos e estudos mais significativos. A seguir, apresentamos um exemplo de como se dava esse encaminhamento às crianças:

Figura 1 - Atividade com sugestão do tema "As rodas de conversa no NEI"

\begin{tabular}{|c|}
\hline ATIVIDADE DE LÍNGUA PORTUGUESA - MEMORIAL \\
\hline $\begin{array}{l}\text { As rodas de conversa no NEI são preciosos momentos que temos em nossa rotina! } \\
\text { Nela conversamos sobre noticias, discutimos os conflitos que acontecem em sala, } \\
\text { trocamos ideias, ouvimos músicas, damos sugestões e conselhos, realizamos votações, } \\
\text { fazemos enquetes etc. A roda de conversa torna nossa rotina escolar mais rica, } \\
\text { prazerosa e divertida. }\end{array}$ \\
\hline $\begin{array}{l}\text { Vamos relembrar das rodas de conversa que marcaram a nossa rotina aqui no NEI } \\
\text { e que de uma forma ou de outra deixaram marcas em você? Para isso, registre os } \\
\text { momentos da roda de conversa que você teve ou tem na escola, em um novo capitulo de } \\
\text { suas memórias, intitulado: "As rodas de conversa no NEI!". Nessa produção, você poderá } \\
\text { resgatar as rodas de conversas que mais marcaram a sua trajetória aqui na escola e sua } \\
\text { importância em nossa rotina. }\end{array}$ \\
\hline $\begin{array}{l}\text { Capriche na estruturação dos parágrafos, seguindo todas as orientações dadas nas } \\
\text { aulas de Lingua Portuguesa! Não esqueça de organizar seu texto com uma introdução, } \\
\text { desenvolvimento e conclusão! }\end{array}$ \\
\hline
\end{tabular}

Fonte: acervo das autoras.

A sugestão para o registro dos momentos da "roda de conversa", enquanto momento na rotina que acontece desde a educação infantil, partiu de nós, professoras, ao percebermos que esse era um momento muito significativo para as crianças. Era nesse espaço privilegiado da rotina que os "contratos ocorriam", as crianças externavam mais esponta- neamente as reivindicações de seus direitos e exerciam seu poder decisório, tornando-se assim um espaço institucional de fala e de escuta sobre fatos em que elas concordavam ou discordavam.

Era na roda que conseguiam discutir entre elas mesmas e com as professoras sobre o que ocorria ao seu redor e no mundo. Traziam 
suas versões do que ouviam nos noticiários e de como se resolviam conflitos cotidianos. Ali também era um espaço de bem-estar, onde ouviam músicas, declamavam poesias, chegavam a consensos.

Para Vygotsky (2002, p. 78), “Quanto mais formos capazes de dar conta a nós mesmos e aos outros da experiência vivida, mais ela é vivida conscientemente". Se vivências cotidianas do ambiente escolar como a "roda de conversa" eram promotoras de aprendizagens para nós, professoras, tratava-se de saber se elas eram para as crianças. Será que conseguiam refletir e perceber de modo consciente essa prática como significativa? O que "ficava" das rodas para elas? Como escreveriam sobre suas práticas cotidianas? Como avaliavam esses momentos? Imbuídas por esses questionamentos, lançamos a proposta para que elas escrevessem sobre "as rodas de conversa na escola". Sobre esse encaminhamento, trazemos um trecho escrito por uma criança em 2018.

Figura 2 - Registro de uma criança sobre a roda de conversa

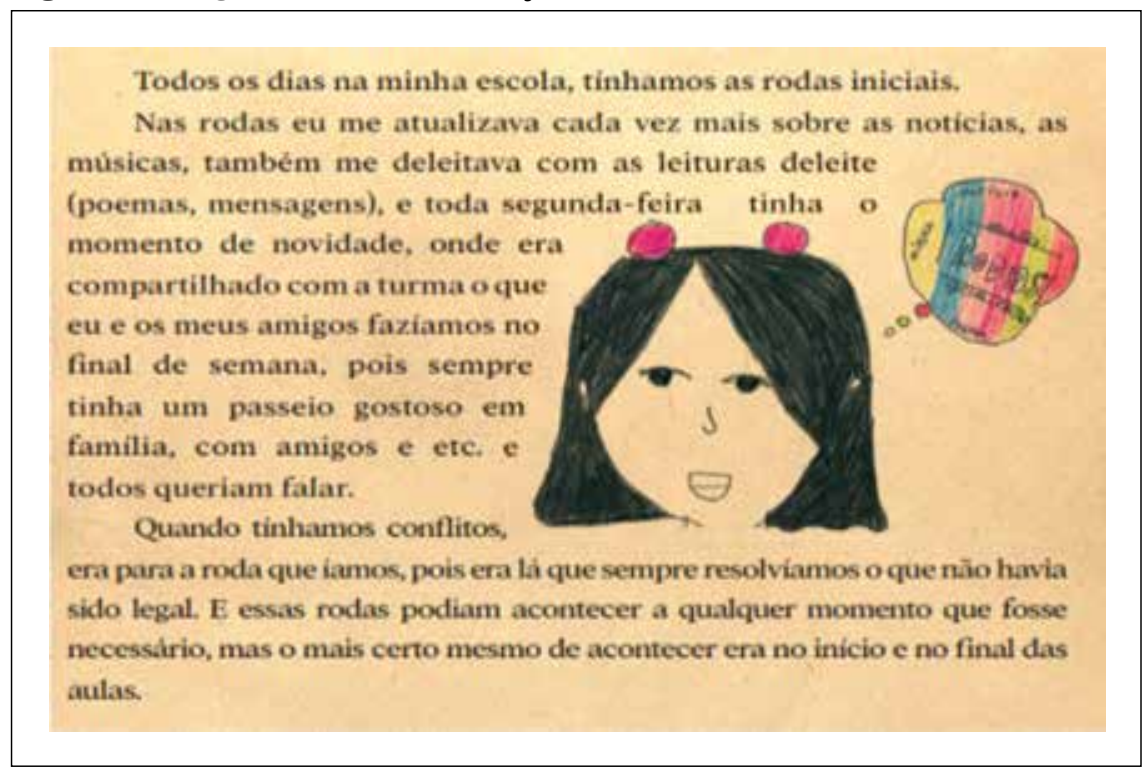

Fonte: Nazário e Costa (2018).

A narrativa da criança, exposta no livro organizado por Nazário e Costa (2018), indica que ela enxergava esse momento como significativo, pois pontua e reflete sobre vários aspectos: atualizar-se sobre as notícias, o prazer de ler; falar de momentos agradáveis e resolver conflitos, ela lembra que os momentos das rodas eram realizados no início e no final da aula e reconhece que todos "queriam falar", o que demonstra envolvimento por parte de toda turma. Seu registro é representativo com relação aos textos de outras crianças que conseguem, assim como ela, externar sentimentos e reflexões, em um movimento de retomada dessa vivência, o que atesta a funcionalidade social das "rodas de conversa".

Outras propostas de momentos do cotidiano também aconteceram. Em algumas ocasiões, as próprias crianças também sugeriam temáticas, como, por exemplo, o registro de visitas de estudo, os bichos que viram ou estudaram na escola, dentre outros.

Nas orientações que dávamos às crianças, como no exemplo da Figura 1, comumente registrávamos pontos que, durante o processo de escrita, percebíamos certa dificuldade das crianças, como a organização do texto em parágrafos, a importância de uma introdução, 
um desenvolvimento e uma conclusão para fechar o texto. Nesse sentido, nossas orientações para a produção escrita se voltavam para a temática, sugerida por nós ou pelos próprios alunos. Apesar de apresentarmos orientações específicas, conforme apresenta a Figura 1, valorizávamos e privilegiávamos a escrita espontânea das crianças, sempre sugerindo melhorias quando havia necessidade, principalmente quanto aos aspectos de coerência e coesão textuais.

Após a escrita dos textos, as crianças podiam socializar suas memórias, realizando uma leitura espontânea nos momentos de roda de conversa ou na hora da história. Em seguida, entregavam às professoras para que fizessem a leitura. Depois, quando necessário, devolvíamos o texto com orientações para que o estudante pudesse fazer suas alterações e, dessa forma, enriquecer seus textos. Esse processo de reescrita, conforme esclarecido, visava à melhoria na compreensão do texto, não tinha como foco as regras gramaticais.

Em outro momento, os próprios alunos liam os textos dos colegas e podiam sugerir melhorias. A etapa da escrita e reescrita dura praticamente todo o ano letivo, concomitante a ela, continuamos estudando com as crianças acerca do gênero, bem como realizando leituras de textos literários que remetem a memórias. Para Antunes,

A maturidade na atividade de escrever textos adequados e relevantes se faz assim, e é uma conquista inteiramente possivel a todos, mas é 'uma conquista', 'uma aquisição', isto é, não acontece gratuitamente, por acaso, sem ensino, sem esforço, sem persistência. Supõe orientação, vontade, determinação, exercício, prática, tentativas (com rasuras, inclusive!), aprendizagem. Exige tempo, afinal! (ANTUNES, 2003, p. 60)

Por isso, durante todo o ano, o trabalho pedagógico com o memorial exige criatividade, diálogo, interação, troca entre crianças e professores, mantendo sempre o foco na natureza do texto memorialístico e na sua função social.

No decorrer do 5o ano, as crianças produzem cerca de dez textos memorialísticos com temáticas diversas. No 2 o semestre, os escritores escolhem três textos para compor o seu capítulo individual. Assim, após a escolha, têm a oportunidade de digitar as memórias escolhidas em um processador de textos, nos computadores da sala de informática da instituição.

Figura 3 - Digitação dos textos

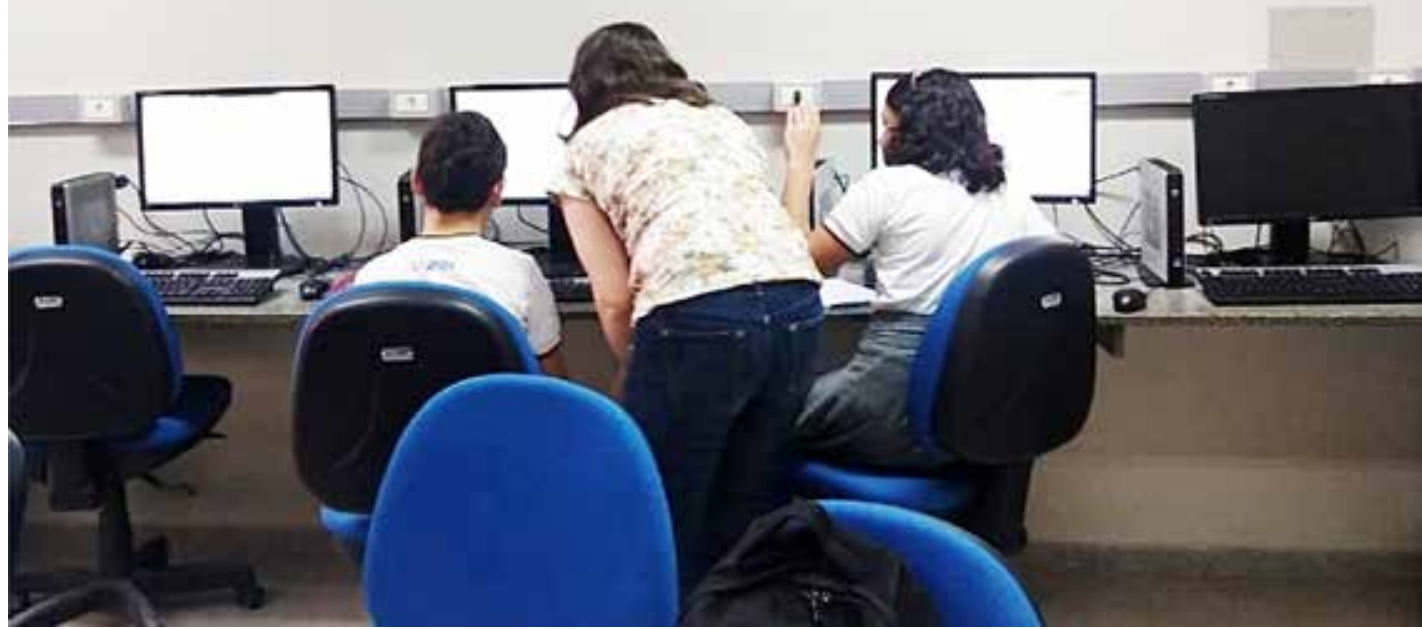

Fonte: banco de dados das autoras. 
Na ocasião, conforme evidenciado na Figura 3, as professoras fazem mediações, sugerindo às crianças melhorias no texto, agora, ainda mais perto da feitura final do livro, em um processo de resgate de memórias, que envolve constante conversa e reflexão sobre o que foi vivido e registrado, e que se aproxima de se tornar público.

Ainda no processo de escrita, escrevemos coletivamente a apresentação do livro, a dedicatória e os agradecimentos e convidamos um ex-professor da referida turma para escrever o prefácio do livro. É importante frisarmos que, quando as crianças escolhem determinado professor para escrever o prefácio do livro, elas recorrem às suas memórias escolares, e escolhem alguém que marcou afetivamente a história dessa turma. Com isso, o resultado é um sentimento de gratidão de ambas as partes. Vejamos o prefácio produzido pela professora Cibele Lucena de Almeida, em 2018, por exemplo:

Dei uma volta ao passado, vivido no mesmo corredor que as recebia no ano de 2014 , ou então como professora do 3o ano e elas como crianças recém-chegadas - receosas, principiantes em suas relações com o novo grupo de colegas e professoras, porém desejosas em desbravar o mundo que se apresentava: uma escola que pulsava vida, cor, parque, brinquedo, movimento, areia, fantasia [...]. (ALMEIDA, 2018, p. 7)

A professora falou sobre a experiência que teve por dois anos com essa turma. Além disso, relatou sua "volta ao passado" para relembrar sensações, sentimentos provocados pelos momentos importantes e significativos, vividos por e com esses alunos. Em suma, a escrita do prefácio se constitui como uma rica oportunidade de rememorar, tanto para os alunos, que precisam recordar momentos para a escolha do professor, quanto para o docente, que necessita "biografar-se". Para Bruner (2014, p. 75), [...] "dizer é fazer, biografar-se é tornar-se um outro para construir-se como um si mesmo". Portanto, a escrita do prefácio possibilita ao docente, ao escrever, reviver, de modo formativo, as vivências escolares com aquela determinada turma, rememorando práticas e fomentando reflexões.

Dando continuidade aos procedimentos de elaboração do memorial escolar, ressaltamos que a produção dos memoriais se deu a partir da colaboração coletiva dos atores envolvidos no processo de escrita - colegas, professores, familiares -, posto que, compreendemos a importância do coletivo na constituição singular dos sujeitos, como também porque todas as crianças são consideradas sujeitos de direitos de participação e aprendizagens, independentemente de suas condições, ao longo da trajetória escolar.

Desse modo, em uma perspectiva inclusiva, foi preciso adaptar as possibilidades de registro àquelas crianças que ainda não escreviam autonomamente, pois não faziam uso da fala e/ou não estavam alfabetizadas, devido a alguma deficiência. Tais crianças, precisaram da ajuda do coletivo para significar suas vivências escolares, já que, ao longo de sua vida escolar no NEI-CAp/UFRN, externaram e sinalizaram seus gostos e preferências através de comportamentos, linguagens não verbal, observações e relatos das famílias, colegas e professores, e tiveram, assim, seus direitos de participar da elaboração do livro preservados.

A escrita coletiva se constitui como um momento importante, uma vez que promove a tomada de escolhas, a postura de ouvir o outro e suas sugestões, a avaliação crítica dos termos mais adequados a serem utilizados e a discussão do conteúdo a ser priorizado no texto. A partir dessa compreensão, de acordo com a demanda de cada turma, realizamos a escrita em conjunto dos textos de crianças público-alvo da educação especial. Tendo por base que cada autor tinha direito à escolha de três tex- 
tos para a composição do seu capítulo no livro, como critério de escolha para a criança com deficiência, escolhemos um texto que foi mediado pelas professoras, um em parceria com a família das crianças com deficiência e outro, com os colegas da turma.

No processo de escrita do memorial escolar no NEI-CAp/UFRN, os alunos também realizam a ilustração de todo o livro, que é organizado em três principais momentos. No primeiro mo- mento, as crianças participam de uma oficina com um professor colaborador sobre autorretrato. $\mathrm{Na}$ ocasião, refletem sobre as técnicas para melhor demarcar os traços marcantes do rosto. Os capítulos do memorial foram compostos por três textos de cada criança, assim, na abertura dos capítulos, há uma pequena apresentação sobre cada criança, acompanhado do seu autorretrato. Na Figura 4, observamos os autorretratos de duas crianças do livro de 2019.

Figura 4 - Autorretratos

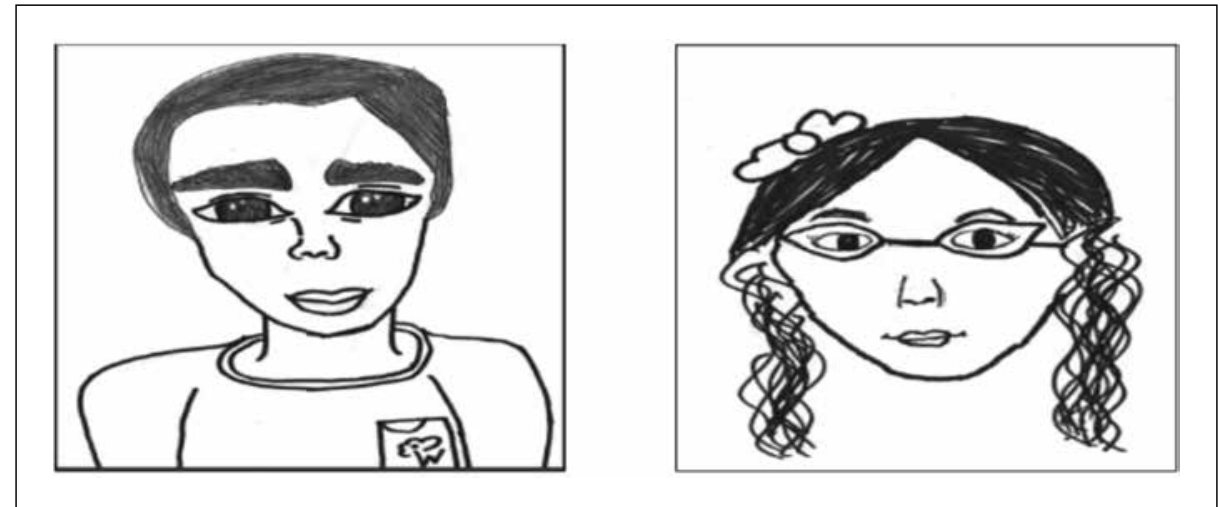

Fonte: Gomes e Costa (2019).

No segundo momento do processo de ilustração, as crianças ilustram suas três memórias, de acordo com a temática de cada texto.
Na Figura 5, verificamos a ilustração das memórias de "rodas de conversa" e dos professores mais marcantes de uma criança.

Figura 5 - Ilustração dos textos

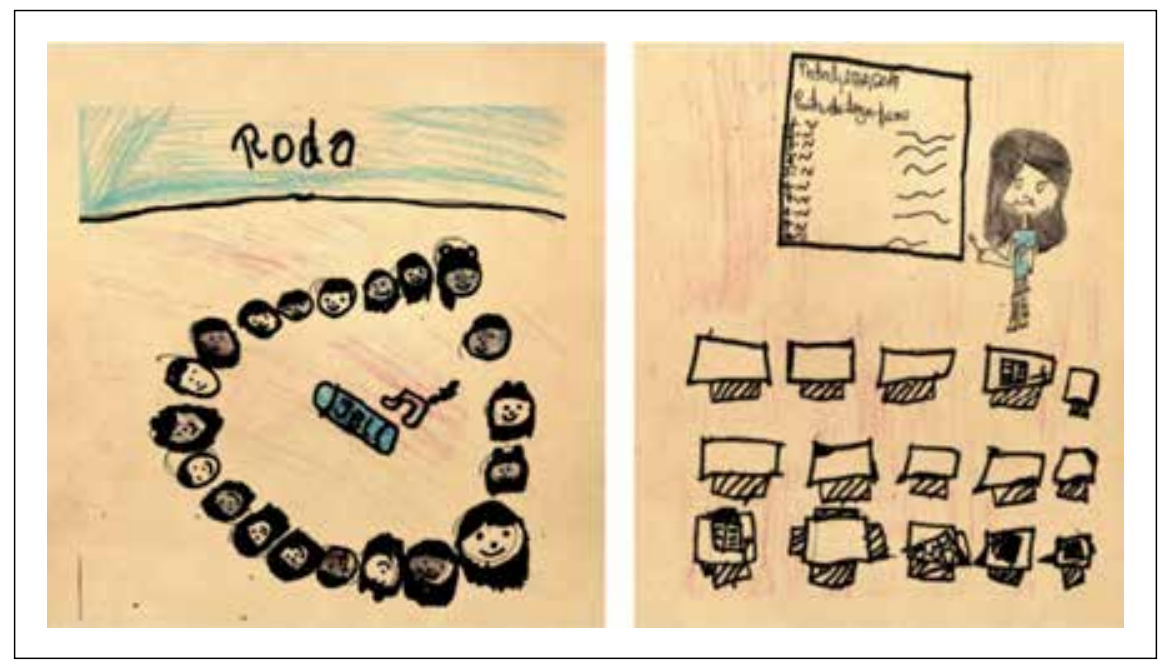

Fonte: Gomes e Costa (2019).

Ainda com relação ao aspecto ilustrativo, em um terceiro momento, é uma prática no $\mathrm{NEI}$, lançar um concurso voluntário com os alunos do 5o ano para a escolha da capa. As ilustrações podem ser vistas a seguir, nas Figuras 6 e 7: 
Figura 6 - Capa do livro publicado em 2018

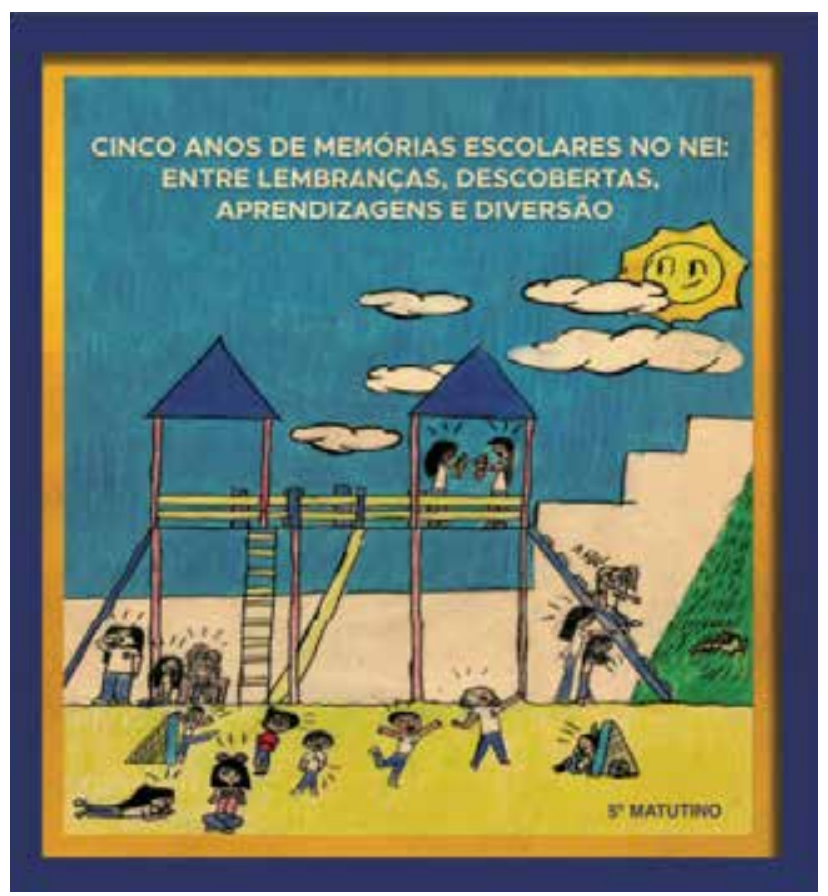

Fonte: Nazário e Costa (2018).

Conforme evidenciado nas Figuras 6 e 7, as ilustrações remetem a relações de dinamismo, movimento, amizade, brincadeiras, descobertas, vividos nesse lugar, assim como de objetos e simbolos escolares que apresentam algum significado no contexto das memórias escolares das referidas turmas, a ilustração, portanto, também se configurou como um fomento à reflexão sobre a vida escolar.
Figura 7 - Capa do livro publicado em 2019

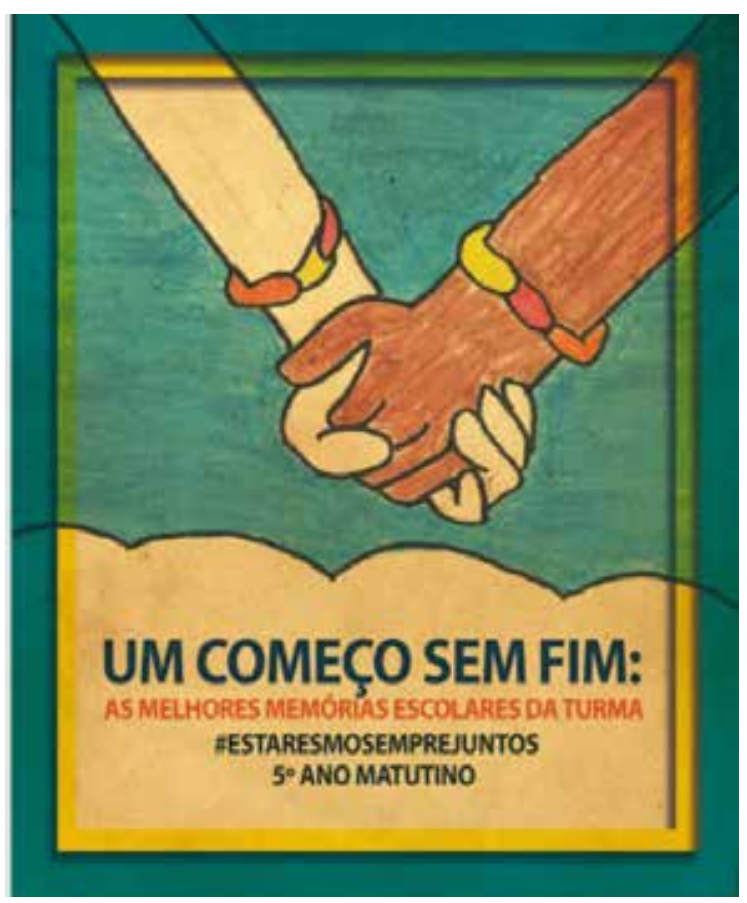

Fonte: Gomes e Costa (2019).

Após a organização estrutural do livro junto às crianças, enviamos o arquivo digital para o diagramador. Ressaltamos que a diagramação nos dois anos foi feita voluntariamente por um pai de uma criança matriculada em 2018 no 5o ano do turno vespertino de nossa instituição.

Após as atividades de planejamento, escrita e reescrita dos textos, partimos para a última etapa, evidenciada no Quadro 3.

Quadro 3 - Etapa de publicação do livro de memórias

Objetivos da etapa de publicação do livro de memórias
Participar do lançamento do livro de memórias escolares, publicado no site da instituição

Fonte: elaborado pelas autoras.

Realizamos o lançamento dos livros e sua publicação consta no repositório digital da instituição. Em 2018, no entanto, além do lançamento que já existe como prática ao final do ano letivo no NEI, as crianças e professoras foram convidadas para o pré-lançamento do livro de Nazário e Costa (2018) no Colóquio internacional de Pesquisa (Auto)Biográfica com crianças e jovens (II CINPAC), que abor- dou o tema: “infâncias e juventudes e espaços escolares e não escolares". Essa foi uma rica oportunidade de apresentação das crianças, que, muito entusiasmadas, puderam falar pela primeira vez em público, em um evento científico, de modo simples, consciente e reflexivo, sobre o processo e finalização de seus escritos, que culminou naquele livro de memórias ali pré-lançado. 
Após a vivência dos procedimentos mencionados para a elaboração do livro, como professoras participantes do processo, definimos o memorial escolar como um rico material em que as crianças do 5o ano expressaram seus sentimentos em relação a temáticas do âmbito escolar, por isso, desde o início do processo, assumimos o posicionamento de professoras -pesquisadoras, pois, durante todo o processo de escrita do memorial e, após os procedimentos de produção do livro, mais precisamente, retomamos os escritos com o intuito de investigá-los, de modo a analisar as reflexões das crianças ali presentes.

Na próxima seção, abordamos nossas análises acerca da escrita reflexiva das crianças sobre a escola e algumas práticas escolares.

\section{Escrita reflexiva de crianças sobre}

\section{a escola: uma análise a partir do memorial escolar}

Na presente seção, apresentamos as análises, realizadas a partir da leitura dos dois livros de memórias dos quinto anos matutinos de 2018 e 2019.

As análises visam reconhecer reflexões suscitadas pelas crianças acerca da escola: seus sentimentos, medos, dificuldades, facilidades etc. Buscamos, assim, destacar expressões e termos linguísticos que expressavam sentimentos e emoções. Ao reler os textos das crianças, fomos guiadas pela busca em identificar reflexões sobre o que elas sentiram no decorrer da escrita do memorial e quais os significados que elas atribuíram a escola e às diversas práticas escolares. Para Passeggi, "no ato de biografar-se, contar suas próprias experiências, a criança operacionaliza as ações de lembrar, de refletir, projetar-se no futuro e encontrar alternativas, que incidem sobremaneira sobre o seu desenvolvimento como ser social e histórico" (2018, p. 112).
Em um primeiro momento, lemos os livros de 2018 e 2019 e selecionamos quatro temáticas em comum nesses livros, que foram: a concepção de escola, as aulas de matemática, os momentos de leitura e as brincadeiras vivenciadas na escola. Assim, para fins de compilação dos dados de análise, copiamos um trecho de cada livro e organizamos um quadro para cada temática. Esses fragmentos foram selecionados à medida em que percebíamos uma narrativa singular, pessoal e explicativa acerca das concepções de escola, das aulas de matemática, dos momentos de leitura e das brincadeiras realizadas no âmbito escolar. Entendemos que

[...] pela reflexividade autobiográfica, a criança dota-se da possibilidade de se desdobrar como espectador e como personagem do espetáculo narrado; como pensador e como objeto pensado; enfim, como objeto de reflexão e como ser reflexivo. Essa relação dialógica entre o ser e a representação de si revela a disposição à reflexividade autobiográfica e confere ao humano um modo próprio de existência. Essa disposição humana à reflexividade é aqui entendida como probabilidade de o indivíduo (criança, jovem, adulto) voltar-se sobre si mesmo para tentar explicitar o que sente ou até mesmo perceber que fracassa nessa difícil tarefa de (re) elaboração da experiência vivida, mediante instrumentos semióticos disponiveis (em suas mais diversas grafias). (PASSEGGI et al., 2014, p. 89).

Assim, por possibilitar a reflexão sobre momentos vividos na escola e valorizar os significados deles, buscamos, em nossa leitura dos textos das crianças, trechos que de algum modo refletissem um sentimento acerca da escola, das aulas de matemática, dos momentos de leitura e das brincadeiras. Para fins de organização e análise dos dados, nos baseamos em Passeggi, Nascimento e Rodrigues (2018). Adaptamos o quadro sintético apresentado pelos autores, no qual copiamos trechos dos registros escritos de dois alunos, um de cada ano letivo - 2018 e 2019, na coluna esquerda; na do meio, apontamos nossa reflexão sobre 
a escrita dessas crianças; e, na última coluna, apresentamos três palavras-chave que sintetizam os significados da narrativa da criança.

Ressaltamos que os trechos selecionados representam, de modo geral, pontos em co- mum sobre a mesma temática que também foram destacados na escrita de outras crianças. No Quadro 4, apresentamos trechos da escrita autoral das crianças em relação ao ambiente escolar.

Quadro 4 - Reflexões das crianças sobre a escola

\begin{tabular}{|l|l|l|}
\hline \multicolumn{1}{|c|}{ Trecho da escrita das crianças } & \multicolumn{1}{|c|}{ Sentença sintética } & \multicolumn{1}{c|}{ Palavras-chave } \\
\hline $\begin{array}{l}\text { Essa escola é pública, mas é muito } \\
\text { melhor que muitas particulares } \\
{[. . .] \text { só sei é que fui privilegiada }} \\
\text { de estudar nessa escola de } \\
\text { qualidade. (Nazário. Costa, 2018, } \\
\text { p. 41) }\end{array}$ & $\begin{array}{l}\text { A escola pública pode ser tão } \\
\text { boa ou melhor do que a escola } \\
\text { particular. Mas não é sempre que } \\
\text { isso ocorre, por isso a criança se } \\
\text { diz privilegiada. }\end{array}$ & $\begin{array}{l}\text { Escola pública. Qualidade. } \\
\text { Privilégio. }\end{array}$ \\
\hline $\begin{array}{l}\text { Se as outras escolas fossem iguais } \\
\text { ao NEl, que respeita a hora dé } \\
\text { brincar das crianças ao invés } \\
\text { de levar muito tempo copiando, } \\
\text { escrevendo e escutando o } \\
\text { professor, tudo seria bem melhor! } \\
\text { (Gomes. Costa, 2019, p. 69) }\end{array}$ & $\begin{array}{l}\text { A escola é boa porque valoriza } \\
\text { os momentos de brincadeira e } \\
\text { o equilíbrio entre o brincar e as } \\
\text { aulas com práticas "tradicionais". }\end{array}$ & $\begin{array}{l}\text { Brincadeiras na escola. } \\
\text { Respeito. Infância. }\end{array}$ \\
\hline
\end{tabular}

Fonte: organizado pelas autoras.

Conforme apresentado no Quadro 4, por meio da escrita das crianças, compreendemos que as mesmas concebem a escola como um local de qualidade e isso, para elas, se deve a vários fatores, tornando-a "muito melhor" que outras escolas. Visualizamos então, um entendimento acerca da diferença social entre instituições públicas e privadas e a valorização da escola em que estudam por oferecer espaços e momentos agradáveis. As crianças percebem a escola como um local de direitos, de aprendizado, mas também de afetividade e ludicidade ao valorizarem o equilíbrio que vivenciam no cotidiano escolar entre "a hora de brincar" e "a hora de estudar, copiar, escrever".

Verificamos que elas utilizam a comparação ao fazerem referência a práticas de "outras escolas" e se sentem privilegiadas por estudarem nesse local. Assim, a escrita do memorial fomentou nas crianças reflexões não apenas sobre a escola em que estudam, mas possibilitou um olhar panorâmico e ao mesmo tempo singular de práticas escolares e da necessidade da relação entre a brincadeira, a ludicidade e os momentos de estudos formais. A respeito disso, concordamos com Dowbor, ao enfatizar que:

[...] acho necessário pensar a educação numa perspectiva humanista. Ora, na verdade, a escola pode possibilitar um espaço de aprendizagem não unicamente racional, mas também corpóreo e emocional. Não há por que ter vergonha de viver o que se sente e deseja. Por isso, posso desejar uma escola que não seja local somente de fala, de discursos autoritários, mas também de escuta de respostas às expectativas do aluno, uma escola que ouça mais os anseios e necessidades dos seus alunos, profissionais e pais. (DOWBOR, 2008, p. 56)

Os registros do memorial escolar possibilitam definir conscientemente e valorizar a escola como um ambiente que precisa difundir práticas que respeitem os sujeitos como seres integrais, respeitando suas emoções, singularidades, seu corpo e sua racionalidade.

De modo mais específico, acerca das práti- 
cas escolares, o Quadro 5, a seguir, demonstra fragmentos sobre o que as crianças pensam e sentem sobre as aulas de matemática. Desta- camos os trechos-chave, que expressavam de algum modo essas sensações, fossem elas prazerosas ou não.

Quadro 5 - Reflexões sobre as aulas de matemática

\begin{tabular}{|c|c|c|}
\hline Trecho da escrita das crianças & Sentença sintética & Palavras-chave \\
\hline $\begin{array}{l}\text { E é por isso que eu adoro a Ma- } \\
\text { temática, por que nós podemos } \\
\text { aprender brincando, nos diver- } \\
\text { tindo muito (Nazário. Costa, 2018, } \\
\text { p. 74) }\end{array}$ & $\begin{array}{l}\text { A matemática é uma matéria es- } \\
\text { colar divertida porque com ela é } \\
\text { possivel aprender brincando. }\end{array}$ & $\begin{array}{l}\text { Matemática. Brincadeiras. } \\
\text { Aprendizagem. }\end{array}$ \\
\hline $\begin{array}{l}\text { Não foi fácil para mim aprender } \\
\text { matemática [...] Agora a minha } \\
\text { disciplina favorita sem dúvidas } \\
\text { nenhuma é a matemática, pois } \\
\text { números dificeis se tornaram um } \\
\text { bom passatempo para mim [...] } \\
\text { aprendi diversas coisas diferen- } \\
\text { tes na matemática como: contar, } \\
\text { somar, subtrair, multiplicar, divi- } \\
\text { dir e resolver problemas. Também } \\
\text { aprendi a usar o ábaco, o trans- } \\
\text { feridor, o material dourado e etc } \\
\text { (Gomes. Costa, 2019, p.76) }\end{array}$ & $\begin{array}{l}\text { A matemática se tornou uma ma- } \\
\text { téria prazerosa por meio de aulas } \\
\text { com materiais concretos e jogos, } \\
\text { bem como o reconhecimento de } \\
\text { diversas práticas que podem ser } \\
\text { realizadas com o conhecimento } \\
\text { matemático. }\end{array}$ & $\begin{array}{l}\text { Matemática. Materiais } \\
\text { concretos. Superação. }\end{array}$ \\
\hline
\end{tabular}

Fonte: organizado pelas autoras.

Em síntese, com relação aos sentimentos e opiniões sobre as aulas de matemática, a leitura dos trechos da escrita memorialística de formação escolar expostos no Quadro 5, nos fizeram concluir que essas crianças têm uma afinidade com a referida disciplina não pelo conteúdo em si, mas por três principais motivos: 1) pela forma como aprendem - utilizando materiais concretos e participando de jogos e brincadeiras; 2 ) porque esses momentos possibilitam interações com os colegas, ou seja, há uma valorização do coletivo ao utilizar a 1a pessoa do plural "nós podemos aprender brincando"; e 3) pelo reconhecimento da importância da matemática no cotidiano, o que gera um maior interesse em estudá-la, ou seja, eles atestam a importância das aprendizagens escolares para a prática social.
As reflexões das crianças sobre a matemática, por meio de narrativas memorialísticas, se mostram como um campo de investigação precioso para formação de professores que atuam na educação das infâncias, uma vez que, por meio desses registros, é possível identificar lacunas, convergências, divergências, preferências, dificuldades dos sujeitos, de modo que fomentam tanto no aluno quanto no professor a necessidade de se pensar sobre a aprendizagem e ensino da matemática. Para Nacarato, Moreira e Custódio (2019), os estudos (auto) biográficos relacionados à educação matemática estão em crescimento, contudo, para nós, é preciso que se amplie e se explore ainda mais investigações de narrativas matemáticas com crianças.

A leitura também é uma temática propícia para investigar os sentimentos e a visão das 
crianças com relação a práticas recorrentes do ambiente escolar. Selecionamos fragmentos de dois textos dos livros, um de 2018 e outro de 2019 e apresentamos no Quadro 6.

Quadro 6 - Reflexões sobre os momentos de leitura na escola

\begin{tabular}{|c|c|c|}
\hline Trecho da escrita das crianças & Sentença sintética & Palavras-chave \\
\hline $\begin{array}{l}\text { Na escola, eu gostava de ler na biblio- } \\
\text { teca. Lá eu lia livros e gibis com mi- } \\
\text { nhas amigas [...] acho que a leitura é } \\
\text { importante porque com ela aprende- } \\
\text { mos muitas coisas sobre como, por } \\
\text { exemplo: respeitar as pessoas e não } \\
\text { julgar pelas aparências. Quando le- } \\
\text { mos, aperfeiçoamos nossas leituras, } \\
\text { passamos a ter mais imaginação para } \\
\text { escrever e aprendemos sobre várias } \\
\text { coisas (Nazário. Costa, 2018, p. 24) }\end{array}$ & $\begin{array}{l}\text { A leitura é importante por } \\
\text { diversos motivos. Ela colabora } \\
\text { na formação dos sujeito, em } \\
\text { suas atitudes e também em sua } \\
\text { cognição. }\end{array}$ & $\begin{array}{l}\text { Leitura. Aprendizagens. } \\
\text { Reconhecimento. }\end{array}$ \\
\hline $\begin{array}{l}\text { No Ensino Fundamental gostei mais } \\
\text { de ler os livros da ciranda. Eu escolhia } \\
\text { um livro de algum colega da turma } \\
\text { e levava para casa na sexta-feira. Eu } \\
\text { gostava muito dessas leituras e sem- } \\
\text { pre apreciei os livros dos meus cole- } \\
\text { gas (Gomes. Costa, } 2019 \text {, p. } 51 \text { ) }\end{array}$ & $\begin{array}{l}\text { A leitura é uma prática presente } \\
\text { no cotidiano escolar, mas que } \\
\text { também pode ser realizada em } \\
\text { casa, de modo prazeroso. }\end{array}$ & $\begin{array}{l}\text { Leitura. Escola. Ambiente } \\
\text { extraescolar. }\end{array}$ \\
\hline
\end{tabular}

Fonte: Organizado pelas autoras

Por meio do recorte dos trechos da escrita do memorial escolar expostos no Quadro 6, concluímos que esse registro possibilitou que as crianças refletissem a respeito da função da leitura, sua importância e potencialidade. Ao relatar que a leitura é relevante porque colabora no aprendizado, faz relaxar ou possibilita a interação com os colegas por meio da leitura coletiva, os sujeitos dos quinto anos reconhecem o ato de ler como uma prática que apresenta diversos objetivos. As crianças também valorizam e reconhecem que a leitura pode ocorrer em diferentes lugares e/ou momentos da rotina e reconhecem essa atividade como uma ocasião de formação, posto que possibilita o desenvolvimento da imaginação e criatividade. As reflexões suscitadas pelas crianças vão ao encontro do que aponta Dowbor (2008, p. 103-104), para ela,

[...] o importante no ato de ler é o aprendizado daquele que se experiencia como leitor, de aprender a conversar com o texto. É pelo aprendizado de conversar com o texto que descobrimos a inter-relação existente entre o texto e o contexto da pessoa que escreveu o texto. Quando escrevemos ou lemos, não o fazemos como se estivéssemos soltos no ar. Fazemo-lo sempre com base naquilo que somos, com a visão de mundo que temos, da qual fazem parte nossos valores, desejos, sonhos, experiências de vida.

Percebemos nos registros das crianças o imenso prazer que elas têm por esses momentos de leitura vivenciados na escola e que faz parte do trabalho desenvolvido pelo $\mathrm{NEI}$, de formar leitores e de primar por livros de qualidade literária. Outra prática bastante vivenciada na escola são as brincadeiras. 0 Quadro 7, a seguir, apresenta fragmentos sobre as brincadeiras vividas na escola. Os termos-chave destacados a seguir mostram que as crianças têm muito prazer em falar desses momentos. 
Quadro 7 - Reflexões sobre as brincadeiras

\begin{tabular}{|c|l|l|}
\hline \multicolumn{1}{|c|}{ Trecho da escrita das crianças } & \multicolumn{1}{|c|}{ Sentença sintética } & \multicolumn{1}{c|}{ Palavras-chave } \\
\hline $\begin{array}{l}\text { A minha brincadeira favorita [...] é } \\
\text { homem morto no chão [...] Graças a } \\
\text { essas brincadeiras temos melhora- } \\
\text { do nosso trabalho de equipe, velo- } \\
\text { cidade, agilidade, entre outros. (Na- } \\
\text { zário. Costa, 2018, p. 94-95) }\end{array}$ & $\begin{array}{l}\text { A brincadeira permite o } \\
\text { desenvolvimento pessoal e a } \\
\text { coletivo. }\end{array}$ & $\begin{array}{l}\text { Brincar. Desenvolvimento. } \\
\text { Coletividade. }\end{array}$ \\
\hline $\begin{array}{l}\text { Acho que brincadeiras é o melhor } \\
\text { jeito de interagir quando você é } \\
\text { criança. Com as brincadeiras, de- } \\
\text { senvolvemos a nossa capacidade de } \\
\text { imaginação, estimulando a criativi- } \\
\text { dade. Adorei fazer este texto, e tinha } \\
\text { desejo de fazer outros como esse de } \\
\text { memórias aqui na escola. (Gomes. } \\
\text { Costa, 2019, p.36) }\end{array}$ & $\begin{array}{l}\text { Brincar é a melhor forma de dender. } \\
\text { aprender. }\end{array}$ & $\begin{array}{l}\text { Brincadeira. Interação. } \\
\text { Aprendizagem. }\end{array}$ \\
\hline
\end{tabular}

Fonte: organizado pelas autoras.

Nos trechos expostos no Quadro 7, observamos a importância da brincadeira na vida das crianças, quando escreve "com as brincadeiras, desenvolvemos a nossa capacidade de imaginação, estimulando a criatividade, o prazer em participar desses momentos de interação, criação e imaginação", percebemos uma tomada de consciência que a criança tem sobre a brincadeira e sua função no desenvolvimento cognitivo e social. Para Winnicott (1975, p. 80), "É no brincar, e somente no brincar, que o indivíduo, criança ou adulto pode ser criativo e utilizar sua personalidade integral: e é somente sendo criativo que o indivíduo descobre o eu (self)".

A escola, portanto, a partir do registro das crianças, é o lugar onde elas brincam, conhecem novas brincadeiras, criam laços, se aproximam uns dos outros, interagem, expressam seus sentimentos e aprendem.

\section{Considerações finais}

Neste artigo, apresentamos os procedimentos de uma prática de escrita por crianças do 50 ano do ensino fundamental, que consideramos inovadora: a produção do memorial es- colar como uma possibilidade de escreverem numa perspectiva reflexiva. Discutimos os procedimentos utilizados e apresentamos as reflexões e concepções das crianças sobre a escola e as seguintes temáticas - aulas de matemática, momentos de leitura, brincadeiras vivenciadas por elas ao longo de seu percurso no NEI - CAp da UFRN, que marcaram sua vida escolar e que foram impressas nos seus escritos memorialísticos no último ano escolar da instituição.

Conforme discutido, a produção de um memorial escolar constitui-se como uma prática desenvolvida ao longo do último ano escolar no NEI-CAp/UFRN desde 2017. Nossa pesquisa foi realizada a partir da análise da escrita de dois memoriais escolares, os dos anos de 2018 e 2019, de crianças com faixa-etária entre 10 e 11 anos, do turno matutino, do 5o ano do ensino fundamental.

Podemos afirmar que a escrita do memorial escolar se configurou, efetivamente, como uma atividade significativa e reflexiva ao proporcionar às crianças o registro de vivências, o que corrobora o pensamento de Vygotsky (2002) quando afirma que "Quanto mais formos capazes de nos dar conta e de dar conta 
aos outros da experiência vivida, mais ela será vivida conscientemente (experimentada, fixada na palavra etc)" (VYGOTSKY, 2002, p. 78).

Concluímos, portanto, que consideramos pertinente a explanação do processo de construção de um livro de memórias escolares posto que "o esforço humano de reflexividade autobiográfica torna as narrativas produzidas pela criança, acerca de suas experiências, um objeto de estudo precioso para o acesso às construções que elas fazem a respeito do que vivem na escola" (PASSEGGI et al., 2014, p. 88), por isso concordamos com o pressuposto de que a criança é um ser de direitos, que possui vivências, as quais podem ser rememoradas, valorizadas, registradas e analisadas.

Com a escrita desse livro de memórias, cada criança foi capaz de criar, construir conhecimentos e apresentar sua própria história. Para nós professoras, isso vem nos mostrar o verdadeiro sentido da escola, como um lugar privilegiado onde "toda variedade de significados aflora, é fácil reaprender, a partir dos próprios guardados, a pluralidade de sentidos formadores que tem a experiência escolar" (ARROYO, 2007, p. 241).

$\mathrm{Na}$ análise realizada para fins deste artigo, foi possivel observar, pelos escritos das crianças, o modo como expressam de maneira ativa, crítica, reflexiva e consciente, os sentimentos delas com relação à escola e práticas vivenciadas com e por elas. Como protagonistas que são, as crianças tornam-se escritoras e autoras de suas histórias de vida e deixam grande legado à instituição e à nossa sociedade.

Para Passeggi, "A reflexividade biográfica permite à criança tomar consciência de si mesma como ator, autor, e agente social [...] é a partir da reflexão [...] que o narrador passa a se assumir como autor responsável pela continuidade de sua história e de sua ação no mundo" (PASSEGGI, 2018, 118-119). Portanto, ao mesmo tempo que escrevem sobre si, as crianças fa- lam conscientemente sobre suas experiências escolares e seus significados e as ressignificam, a partir de um processo autorreflexivo. Enquanto professoras, portanto, nesse exercício de mediação, lançamos a possibilidade de as crianças revelarem não só vozes sobre elas no processo escolar, como também tiveram a oportunidade de apresentar a visão delas acerca de como as coisas funcionam na escola. Os escritos memorialísticos desvelam, assim, concepções de ensino, de aprendizagens, de escola, de criança, de infâncias, e algumas práticas realizadas na instituição, a partir da perspectiva de crianças.

Destarte, ouvir as crianças através dos seus escritos constituiu-se como um "termômetro" para verificarmos se ao longo dos anos escolares, essas crianças tiveram contato com experiências que coadunassem com nossos princípios e práticas. Esse foi um dos desdobramentos que essa tessitura nos proporcionou.

Acreditamos no protagonismo da criança frente ao mundo, por isso, é um dos anseios do NEI-CAp/UFRN enquanto instituição pública, romper com práticas engessadas, que ficam a repetir atividades descontextualizadas, pouco prazerosas e insignificantes para as crianças, como foi possivel ser evidenciado em trechos escritos por elas, apresentado nas análises deste artigo: "Se as outras escolas fossem iguais ao $\mathrm{NEI}$, que respeita a hora de brincar das crianças ao invés de levar muito tempo copiando, escrevendo e escutando o professor, tudo seria bem melhor!" (Gomes. Costa, 2019, p. 69); "podemos aprender brincando, nos divertindo muito" (Nazário. Costa, 2018, p. 74). Privilegiamos a atividade delas, a partir da escuta atenta do que elas têm a nos dizer. Enquanto professoras, abertas ao diálogo, a interação e trocas, acreditamos na possibilidade de refletirmos sobre o ensino e as aprendizagens juntos, nos colocando sempre à disposição para a melhora de nossa práxis pedagógica. 
Portanto, a pesquisa sobre a prática do memorial escolar revela que se trata de uma possibilidade de escrita com ênfase numa perspectiva reflexiva, que se torna significativa, tanto para as crianças, quanto para os professores, pois possibilita a formação consciente das crianças em uma rica troca de conhecimentos e aprendizagens, na medida em que acontecem estudos, reflexões, discussões, questionamentos e aprofundamentos sobre a vivência escolar e possibilita ao professor pesquisar sobre sua prática a partir do que as crianças escrevem sobre si e sobre o que vivenciam na escola. Além disso, um dos caminhos para tornar a aprendizagem de normas gramaticais mais dinâmicas, envolventes e prazerosas para os alunos em fase escolar, pode ser a partir da implementação da escrita memorialista na escola.

\section{Referências}

ALMEIDA, Cibele Lucena de. Um olhar sobre as crianças e o tempo. In: NAZÁRIO, Cláudia Roberto Soares de Macêdo. COSTA, Patrícia Lúcia Galvão da. (Orgs.). Cinco anos de memórias escolares no NEl: entre lembranças, descobertas, aprendizagens e diversão. Natal, RN: Terceirize Editora, 2018. Disponivel em: <http://www.nei.ufrn.br/documentos/2018/336734185> Acesso em: 10 de maio 2020.

ANTUNES, Irandé. Aula de Português: encontro e interação. São Paulo: Parábola Editorial, 2003.

ARROYO, Miguel G. Imagens quebradas: trajetórias e tempos de alunos e mestres. Petrópolis, RJ: Vozes, 2007.

BARBOSA, Tatyana Mabel Nobre. Travessias. In: PASSEGGI, Maria da Conceição; BARBOSA, Tatyana Mabel Nobre (Org.). Memórias, memoriais: pesquisa e formação docente. São Paulo: Paulus; Natal: EDUfRN, 2011. p. 171-227.

BOGDAN, Robert; BIKLEN, Sari Knopp. Investigação qualitativa em educação: uma introdução à teoria e aos métodos. Porto: Porto, 1994.
BRUNER, J. Fabricando histórias. Direito, Literatura, Vida. Trad. Marcos A. G. Domingues. Porto Alegre: Artes Médicas, 2014.

DOWBOR, Fátima Freire. Quem educa marca o corpo do outro. São Paulo: Cortez, 2008.

FERNANDES, Gildene Lima de Souza; SOUZA, Danielle Medeiros de; FREITAS, Alessandra Cardozo de. Ler, rememorar e escrever: Um diálogo entre o ensino de literatura e a produção textual. In: V Congresso Internacional de Literatura Infantil e Juvenil do CELLIJ, edição 5, 2017, Presidente Prudente. Anais... Presidente Prudente, 2017.

GOMES, Luanna Priscila da Silva. COSTA, Patrícia Lúcia Galvão da. (Orgs). Um começo sem fim: as meIhores memórias escolares da turma. Natal, RN: Terceirize Editora, 2019. Disponivel em: <http://www. nei.ufrn.br/documentos/2019/336734186>. Acesso em: 14 mai 2020.

NACARATO, Adair Mendes; MOREIRA, Kátia Gabriela; CUSTÓDIO, Iris Aparecida. Educação Matemática e estudos (auto) biográficos: um campo de investigação em construção. Revista Brasileira de Pesquisa (Auto)Biográfica, Salvador, v. 04, n. 10, 2019, p. 2147. Disponivel em: <https://www.revistas.uneb.br/ index.php/rbpab/article/view/5809> Acesso em: 14 mai 2020.

NAZÁRIO, Cláudia Roberto Soares de Macêdo. COSTA, Patrícia Lúcia Galvão da. (Orgs.). Cinco anos de memórias escolares no NEl: entre lembranças, descobertas, aprendizagens e diversão. Natal, RN: Terceirize Editora, 2018. Disponivel em: <http://www. nei.ufrn.br/documentos/2018/336734185>. Acesso em: 10 de maio 2020.

PASSEGGI, Maria da Conceição. Autoconhecimento: metacompetência para a formação permanente. In: I TELECONGRESSO INTERNACIONAL DE EDUCAÇÃO DE JOVENS E ADULTOS, 1, 2001, Brasília. Anais...Brasília: UnB, 2001.1 CD-ROM.

PASSEGGI, Maria da Conceição. Nada para a criança, sem a criança! In: PASSEGGI et al., Pesquisa auto (biográfica) em educação: infâncias e adolescências em espaços escolares e não-escolares. [Recurso eletrônico] Natal, RN: EDUFRN, 2018. 
PASSEGGI, Maria da Conceição; NASCIMENTO, Gilcilene; OLIVEIRA, Roberto de. As narrativas autobiográficas como fonte e método de pesquisa qualitativa em Educação. Revista Lusófona de Educação, v. 33, n. 33, 2016, p. 11-125. Disponivel em: <https://revistas.ulusofona.pt/index.php/rleducacao/issue/ view/688>. Acesso em: 14 maio 2020.

PASSEGGI, Maria da Conceição; NASCIMENTO, Gilcilene; RODRIGUES, Senadaht. Narrativas de crianças sobre a escola: desafios das análises. Revista Lusófona de Educação, 40, 155-169, 2018. Disponível em: <http://recil.grupolusofona.pt/handle/10437/9324> Acesso em: 10 maio 2020.

PASSEGGI, Maria da Conceição. Narrativas da experiência na pesquisa-formação: do sujeito epistêmico ao sujeito biográfico. Roteiro, Joaçaba, v. 41, n. 1, p. 67-86, jan./abr., 2016. Disponivel em: <https:// portalperiodicos.unoesc.edu.br/roteiro/article/ view/9267>. Acesso em: 10 de maio de 2020.

PASSEGGI, Maria da Conceição et al. Narrativas de crianças sobre as escolas da infância: cenários e desafios da pesquisa (auto) biográfica. Educação. Santa Maria, v 39, n.1, p. 85-104, jan./abr. 2014. Disponível em: <https://periodicos.ufsm.br/reveducacao/article/view/11345> Acesso em: 14 maio 2020.

PASSEGGI, Maria da Conceição; ROCHA, Simone Maria da. A pesquisa educacional com crianças: um estudo a partir de suas narrativas sobre o acolhimento em ambiente hospitalar. Revista Educação em Questão. v. 44, n. 30, 2012, p. 1-23. Disponível em: <https://www.periodicos.ufrn.br/educacaoemquestao/article/view/4080>. Acesso em: 14 maio 2020.

PASSEGGI, Maria da Conceição; SOUZA, Elizeu Clementino de. O movimento (auto)biográfico no Brasil: esboço de suas configurações no campo educacional. Investigación Cualitativa, 2 (1), p. 6-26, 2017. Disponivel em: <https://ojs.revistainvestigacioncualitativa.com/index.php/ric/article/view/56>. Acesso em: 10 maio 2020.

SILVA, José Gomes da. Gênero Textual Memorial. Várzea da Roça - Bahia, 2014. Disponível em: <http://desbravandonossalinguaportuguesa.blogspot.com/2014/11/genero-textual-memorial.html>. Acesso em: 16 set. 2019.

VYGOTSKY, Lev Seminovich. Pensamento e linguagem. 4 ed. Tradução Jefferson Luiz Camargo. São Paulo: Martins Fontes, 2002.

WINNICOTT, D. W. 0 brincar e a realidade. Trad. J. O. A. Abreu e V. Nobre. Rio de Janeiro: Imago, 1975.

Recebido em: 29/05/2020 Revisado em: 01/08/2020 Aprovado em: 05/08/2020

Luanna Priscila da Silva Gomes é doutora em Educação pela Universidade Federal do Rio Grande do Norte (UFRN). Professora no Núcleo de Educação da Infância (NEI) - Colégio de Aplicação (CAp) da (UFRN). Membro do Grupo de Pesquisa em ensino de Matemática e Língua Portuguesa (Contar) da UFRN. E-mail: luanna.gomes1@gmail.com

Patrícia Lúcia Galvão da Costa é mestre em Educação pela Universidade Federal do Rio Grande do Norte (UFRN). Professora no Núcleo de Educação da Infância (NEI) - Colégio de Aplicação (CAp) da UFRN. E-mail: patrilu@gmail.com

Cláudia Roberto Soares de Macêdo Nazário é mestre e doutoranda em Educação pela Universidade Federal do Rio Grande do Norte (UFRN). Professora do Núcleo de Educação da Infância (NEI) - Colégio de Aplicação (CAp) da UFRN. E-mail: claudiamacedo.ufrn@gmail.com 